\title{
PATTERNS OF PREY BIOMASS CONSUMPTION BY SMALL ODONTOCETES IN THE NORTHEASTERN COAST OF VENEZUELA
}

\author{
Lenin E. Oviedo Correa ${ }^{1,2}$
}

\begin{abstract}
Trophic relationships are conditioned by population dynamics of interacting species in the community (species present, food web connections among them, and the strength of interactions), and on the consequences of these species interactions depend various ecosystem processes such as productivity and nutrient flux. Odontocetes target a wide range of prey items and are adapted to feeding at different depths. The aim of this report is to describe the patterns of prey consumption by small odontocetes, incorporating natural predatory patterns into a potential management scheme of strategic food sources, for both human and marine predators. Using the geo-statistical analysis tool of ArcGIS 9.2, maps illustrating the intensity and location of prey consumption were made for species with a sighting index (SPUE) $>0.15$. The biomass consumption emphasized the differences in habitat use by species. The trends in distribution of prey biomass removal by odontocetes particularly suggest a stratification of prey consumption primarily in shelf waters, with a prey biomass that is comprised basically by demersal fish and small pelagics (including Sardinella aurita), and into transition-oceanic depths where most of the predatory pattern would potentially rely on pelagic - mesopelagic squid and myctophids. Overall the spatial tendencies in regionalization presented in this contribution will serve as a base-line to assess ecosystem health and evaluate management scenarios.
\end{abstract}

Keywords: Atlantic ocean; distribution; food/prey; ecosystem; habitat.

\begin{abstract}
RESUMEN
Las relaciones tróficas son reguladas por la dinámica poblacional de las especies que interactúan dentro de la comunidad (especies presentes, conexiones interespecíficas, y nivel de interacción) y de las consecuencias de esas interacciones para procesos del ecosistema como la productividad y el flujo de nutrientes. El objetivo de este reporte es evaluar el patrón de consumo de biomasa por odontocetos de menor tamaño en la costa Nororiental de Venezuela, incorporando patrones de depredación natural a un esquema potencial de manejo de un recurso alimentario estratégico. Por medio de la herramienta de análisis geoestadístico del software ArcGIS 9.2, se elaboraron mapas de densidad en consumo de biomasa de presas para las especies con un índice de avistamiento (SPUE) $>0.15$. El consumo de biomasa de presas enfatiza en el uso diferencial de hábitat por especie. La tendencia en la distribución de la remoción de biomasa de presas por cetáceos odontocetos principalmente sugiere la estratificación del habitat, primeramente en el ámbito de la plataforma continental, con un biomasa de presas que estaría constituida por peces demersales y pequeños pelágicos (entre estos $S$. aurita). Así como en profundidades Transicionales - Oceánicas, donde la mayoría de los patrones de depredación dependerían de organismos pelágicos - mesopelágicos, como calamares y peces mictófidos. Las tendencias espaciales en regionalización, como las que se presentan en es reporte, representan una línea base clave para evaluar la salud de los ecosistemas y escenarios de manejo.
\end{abstract}

Palabras claves: Océano Atlántico, distribución; alimento/presas; ecosistema, hábitat.

1 Proyecto Golfo de la Ballena, Biotropica, Caracas Venezuela.

2 Proyecto Delphinus, Isla de Margarita, Venezuela.biotropicavenezuela@gmail.com.

Recibido 04-V-2009

Aceptado 13-X-2009

DOI: http://dx.doi.org/10.15359/revmar.1.14

Rev. Mar. y Cost. ISSN 1659-455X. Vol. 1. 245-257, Diciembre 2009. 


\section{INTRODUCTION}

The understanding of food webs entail a detailed perception of factors in the interface of community and ecosystem ecology. Trophic relationships are conditioned by population dynamics of interacting species in the community (species present, web connections among them, and the strength of interactions) and on the consequences of these species interactions depend various ecosystem processes such as productivity and nutrient flux (Begon et al. 2006). According to Perez \& McAlister (1993), fish stocks and marine mammals are recognized as interacting components of the marine ecosystem. For the commercially valuable species, knowledge about the degree of competition between fisheries and marine mammal predators is of vital importance. Cetacean distribution is generally related to the presence/absence of their prey (Forcada, 2002). Due to their relatively high energy requirements, cetaceans occur primarily in locations with high potential prey abundance (Pusineri et al. 2008; Costa, 2002). Odontocetes target a wide range of prey items, they can be distributed over wide ranges, and change their distribution seasonally, influenced by the availability of their prey (Forcada, 2002). Different species are adapted to feeding at different depths (Cañadas et al. 2002; Weir et al. 2001; Davis et al. 1998), base on the fact that deeper water is likely to offer more niches to be exploited by marine life (Heithaus \& Dill, 2002; Würsig, 2002). Therefore, the complexity of the cetacean habitat is a key element with implications for foraging success, for instance steep sea floor slopes, such as those typically associated with continental shelf-breaks provides upwelling opportunities by forcing nutrient-rich deep-water currents to the surface, thus promoting a potentially rich foraging environment (Hui, 1979, 1985). This report describes the patterns of spatial distribution in biomass consumption by small odontocete cetaceans within the marine ecosystems off the northeastern coast of Venezuela. This is a key area in terms of biodiversity in the Greater Caribbean eco-region, prey abundance is characterized by the local occurrence of small pelagic species such as round sardinella (Sardinella aurita), associated with habitat productivity due to wind-induced upwelling. There has been a documented decrease in wind force since 2004, resulting in weak upwelling. Consequently, the sardine fishery has decreased since 2003, reaching a critical point in 2005 .

Prey depletion has been an influential factor for cetacean population decrease (particularly common dolphins) in other locations such as the Mediterranean basin (Bearzi et al. 2008), identifying degradation of the food web, where the exploitation of marine resources could lead 
to additional species loss (Coll et al. 2008). The aim of this report is to describe the patterns of prey consumption by small odontocetes in the study area using a spatial approach, looking at the incorporation natural predatory patterns into a potential management scheme of a strategic food source for human and marine predators.

\section{MATERIALS AND METHODS}

\section{Study area}

The study area has been subdivided into four large-scale sections of the five subdivisions proposed by Acevedo et al. (2007) as important areas of conservation for misticete cetaceans (Figure 1). Overall the four sections are comprised by approximately $37 \%\left(>5700 \mathrm{~km}^{2}\right)$ shelf habitat and $63 \%\left(>10500 \mathrm{~km}^{2}\right)$ oceanic environment off the shelf break:

a) The shelf break on the north coast of Margarita Island and La Blanquilla Island (approximate area $6752 \mathrm{~km}^{2}$ ): This portion is a transition zone between the neritic and pelagic habitats. Lesser upwelling centers are present in the northern coast of Margarita Island, including Macanao Peninsula. Although fishermen use the area, it has the lowest level of disturbance due to anthropogenic activities. It is quite important to point out that this location is currently considered for oil industry exploration and development activities in the near future.

\section{Figure 1}

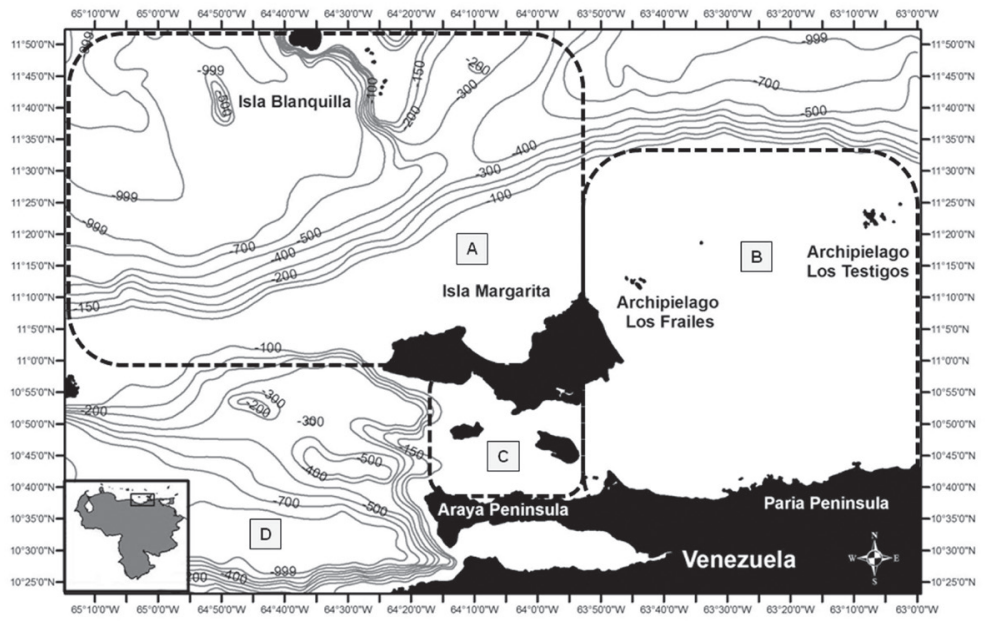

Study Area in Northeastern Venezuela, divided according to Acevedo et al. (2007): (A) The shelf edge on the north coast of Margarita Island and La Blanquilla Island, (B) Margarita Island's eastern coast and Margarita-Los Testigos submarine platform, (C) The northern coast of Araya Peninsula, including Margarita, Coche and Cubagua islands, (D) The Cariaco Basin, southwest of Margarita and Cumaná, including the Cariaco Gulf. 
b) Margarita Island's eastern coast and Margarita-Los Testigos submarine platform (approximate area $3898 \mathrm{~km}^{2}$ ): The continental shelf here is wide and relatively even, with both muddy and muddy-sandy bottom. The latter features mostly constitute a key shallow neritic habitat, also influenced by the upwelling off Carupano's coast (central Paria Peninsula). This zone is subject to traditional uses of its marine resources by people. Coastal population densities have been increasing in recent years and there are also significant land-based sources of pollution associated with port development and tourism.

c) The northern coast of Araya Peninsula, including Margarita, Coche and Cubagua islands (approximate area $1812 \mathrm{~km}^{2}$ ): This region has complex submarine topography due to the presence of Margarita, Coche and Cubagua islands. An area of upwelling is located off north Araya Peninsula; intensity of upwelling is highly influenced by the seasonal variations associated to the trade winds annual cycle. The most important anthropogenic impacts here are fisheries, chemical and acoustic pollution, and commercial shipping traffic.

d) The Cariaco Basin, southwest of Margarita and Cumaná, including the Cariaco Gulf (approximate area $3889 \mathrm{~km}^{2}$ ): Although one portion of this area has National Park status (The Mochima National Park (NP), the human impact on the marine portion of the ecosystem is intense. The threats include fisheries, chemical and acoustic pollution, development of oil and gas production facilities, and commercial shipping traffic.

\section{Small Odontocetes' Sightings and Data Analysis}

Non systematic and systematic data collection on cetacean encounters (sightings) off northeastern Venezuela have been carried out since 1997, resulting in a database with records for more than 10 species: Megaptera novaeangliae, Balaenoptera edeni, B. physalus, Physeter macrocephalus, Tursiops truncatus, Stenella coeruleoalba, S. frontalis, $S$. attenuata, Grampus griseus, Sotalia guianensis and Delphinus spp.

Ninety six sightings records on five species (Table 1) of small odontocetes from 1997-2008 were selected. All records were analyzed using descriptive statistic and integrated into a Geographical Information System (ArcGIS 9.2). Observations yield information on date, time, group size, detectability conditions (wind force by Beaufort scale), geographic coordinates, and effort-corrected (days invested during searches) abundance and sighting indices (APUE and SPUE, respectively).

Additionally, an inference of biomass consumption was done using the 


\section{Table 1}

Odontocetes cetacean's records (1997-2008) incorporated in the analysis: Sighting per unit of effort (SPUE), Abundance per unit of effort (APUE), Biomass (kg), according to Trites \& Pauly (1998), and *Barlow et al. (2008), Total Prey Biomass Consumption (PBC) in Ton $/ \mathrm{km}^{2} /$ Year.

\begin{tabular}{cccccc}
\hline Common name & Scientific name & SPUE & APUE & Biomass & PBC \\
\hline Common dolphin & Delphinus sp & 0.59 & 17.78 & $80^{*}$ & 9734.82 \\
$\begin{array}{c}\text { Atlantic spotted } \\
\text { dolphins }\end{array}$ & Stenella frontalis & 0.28 & 4.84 & 67.50 & 5301.40 \\
$\begin{array}{c}\text { Common bottlenose } \\
\text { dolphin }\end{array}$ & Tursiops truncatus & 0.16 & 1.56 & 203 & 1709.27 \\
$\begin{array}{c}\text { Guiana dolphin } \\
\text { Pantropical spotted } \\
\text { dolphin }\end{array}$ & Sotalia guianensis & 0.10 & 2.87 & 38.60 & 3138.11 \\
\hline
\end{tabular}

species biomass estimates (maximum weight) developed by Trites \& Pauly (1998), and updated by Barlow et al. (2008). Then, following the approach of Read \& Brownstein (2003), the estimates were incorporated to the expression: $I B$ (Ingested Biomass) $=0.123 \mathrm{M}$ ${ }^{0.80}$. Subsequently, the ingested biomass was extrapolated to the density calculated through the APUE, using the approximate total areal extension of NE Venezuela $\left(30000 \mathrm{~km}^{2}\right)$, over a time frame of a year. The relative proportion of small pelagics in the diet was approximated after Pauly et al. (1998), for common dolphins, the proportion was modified after the diet information in Naveira (1996).

Using the geo-statistical analysis tool of ArcGIS 9.2, maps of prey biomass consumption density were done for species with a SPUE $>0.15$. The maps were constructed using the biomass consumption estimates, effort-corrected APUE and geographical coordinates as input parameters, interpolated on a $1.8 \times 1.8 \mathrm{~km}$ grid using gaussian kriging interpolation. Biomass consumption by species was also plotted, with details on the proportion of sardines in their corresponding diet. Confidence intervals of total biomass consumption by species were obtained through a non-parametric bootstrap. Statistical differences between species biomass consumption estimates were established by Kruskal Wallis test, concurring with the non parametric distribution of the sample (Zar, 1996).

\section{RESULTS}

\section{Odontocete occurrence}

From all the odontocete species observed off the NE coast of Venezuela during 1997-2008 (Table 1), the majority of the observations corresponded to the local form of the common dolphin (Delphinus spp.), followed by Atlantic spotted dolphins. 
The dominance of Delphinus spp. encounters was reflected particularly in both, the sighting (SPUE) and the relative abundance (APUE) indices.

\section{Biomass consumption distribution}

The biomass consumption of all five species is presented in Table 1 and illustrated in Figures 2 and 3. The data shows the differences in habitat use by species, tendency that was supported statistically (Kruskal Wallis, $\left.\mathrm{X}^{2}: 14.84 \mathrm{DF}: 3, p<0.05\right)$. Common dolphins, which were dominant in the study area, presented a greater level of consumption within shelf waters. The prey biomass consumption pattern of $S$. guianensis remained confined to coastal waters, in contrast to Stenella dolphins that removed prey biomass located along the shelf's edge and off deeper, transitional waters. Common bottlenose dolphin prey biomass intake was considerable at mid-shelf waters, not close to the continental coastline, but to Island archipelagos within the shelf ecosystem.

The distributions of the biomass consumption pattern agrees with the trend described above (Figures 3-6); biomass removal by common dolphins was mainly concentrated in shelf waters, covering also the deep waters of the Cariaco Basin. Biomass consumption by common dolphins is comprised by an important proportion of small pelagics $(60 \%)$. The highest level of consumption was localized in two key areas: 1) the waters between the south-eastern coast of Margarita Island and the continental coast of central Paria Peninsula, 2) the western side of the Araya Peninsula. Atlantic Spotted Dolphins concentrated their prey biomass removal by predation to the deep waters of the north-eastern portion of the shelf edge, and the western side of Margarita Island toward the Cariaco Basin. The model also showed that spotted dolphin consumption increased progressively from the shelf's edge to deeper waters southwest of La Blanquilla Island. Bottlenose dolphins increased their level of prey removal in the eastern coast of Margarita Island, and around deep waters off the shelf toward the central coast of Venezuela.

\section{DISCUSSION}

Ecological niche as described in here, refers to the biotic and abiotic conditions in which a species is living, that particularly includes the resources it consumes and the way it exploits them (Pianka, 1974). The feeding niche as a subset of the ecological niche would be framed by three major dimensions interconnected: the trophic dimension including diet composition by prey taxa - prey length, the spatial dimension, with the definition of discrete feeding areas (which implies feeding depths) and the temporal dimension. Behavioral traits relative to foraging success 


\section{Figure 2}

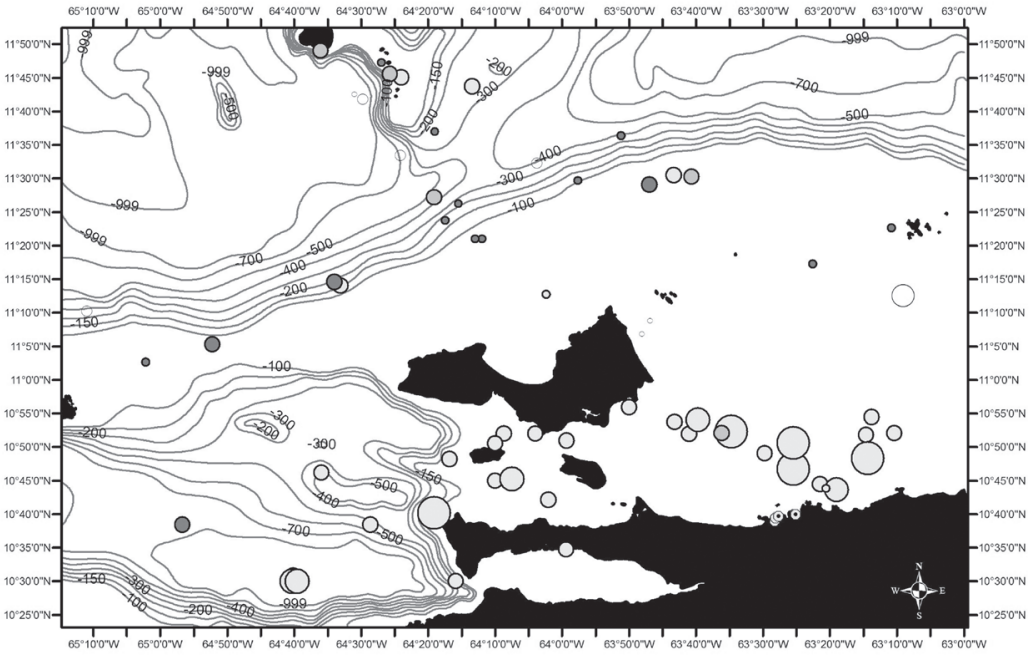

Prey biomass consumption levels by species: Filled circles correspond with common dolphin (light gray), Pantropical spotted dolphins (medium light grey), and Atlantic spotted dolphin (dark grey), small gray filled circles with concentric dot represent Guiana dolphins, and blank unfilled circles common bottlenose dolphins. Circle size is proportional to the level of biomass consumption.

\section{Figure 3}

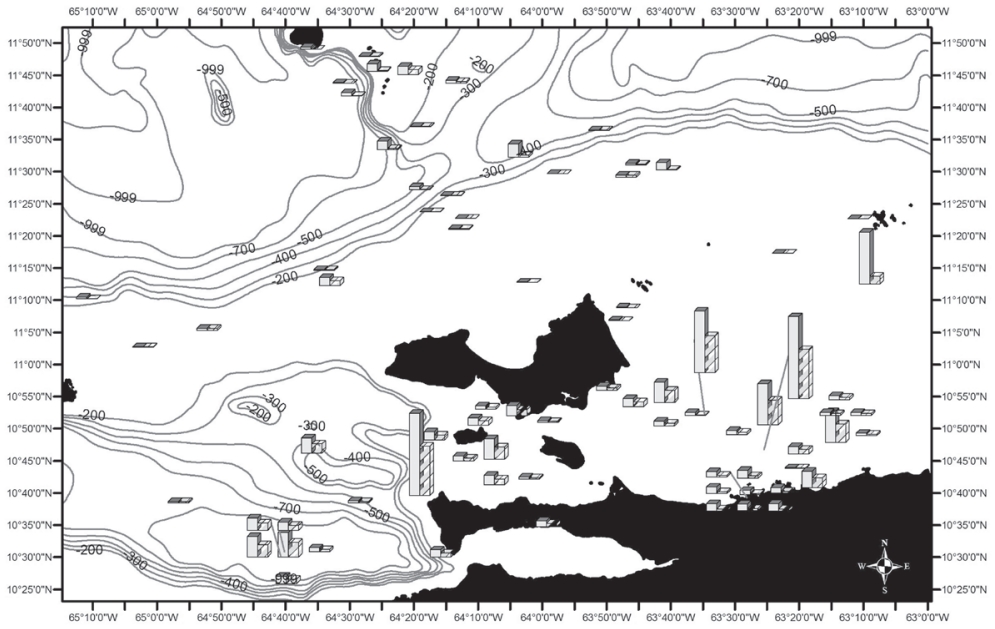

Prey biomass consumption levels by species (solid bar) with details of representative proportion of small pelagic consumed (patterned bar): Common dolphin (60\%), Pantropical spotted dolphins (10\%), Atlantic spotted dolphin (10\%), Guiana dolphins (30\%), and common bottlenose dolphins $(20 \%)$. 


\section{Figure 4}

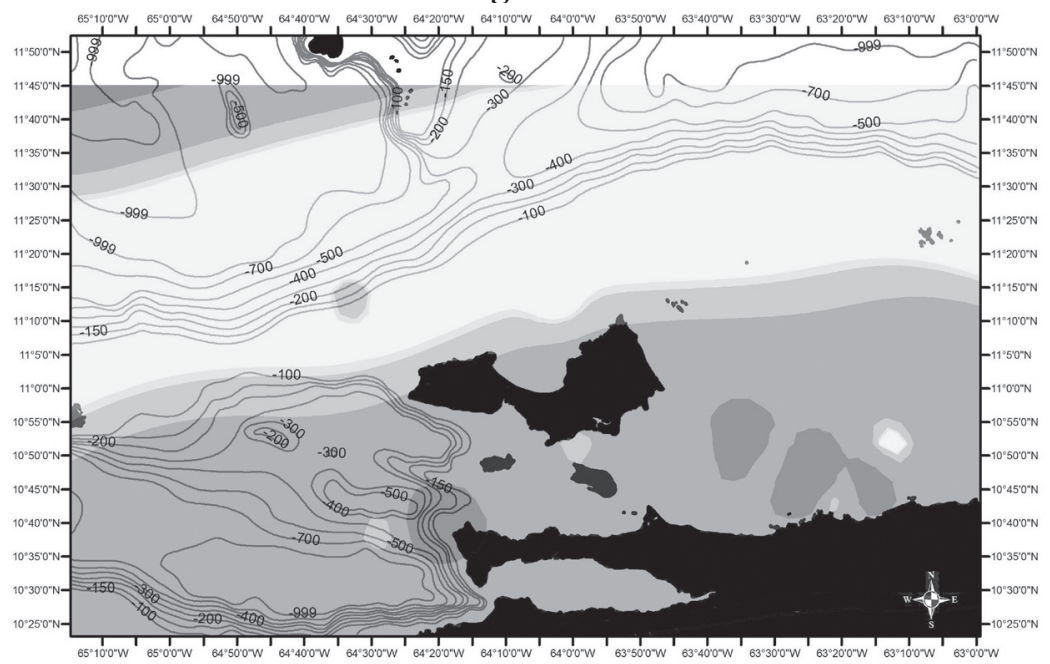

Prey biomass consumption by common dolphin (Delphinus sp), levels on consumption are represented by light gray to the lowest, and dark gray to the highest level of biomass removal.

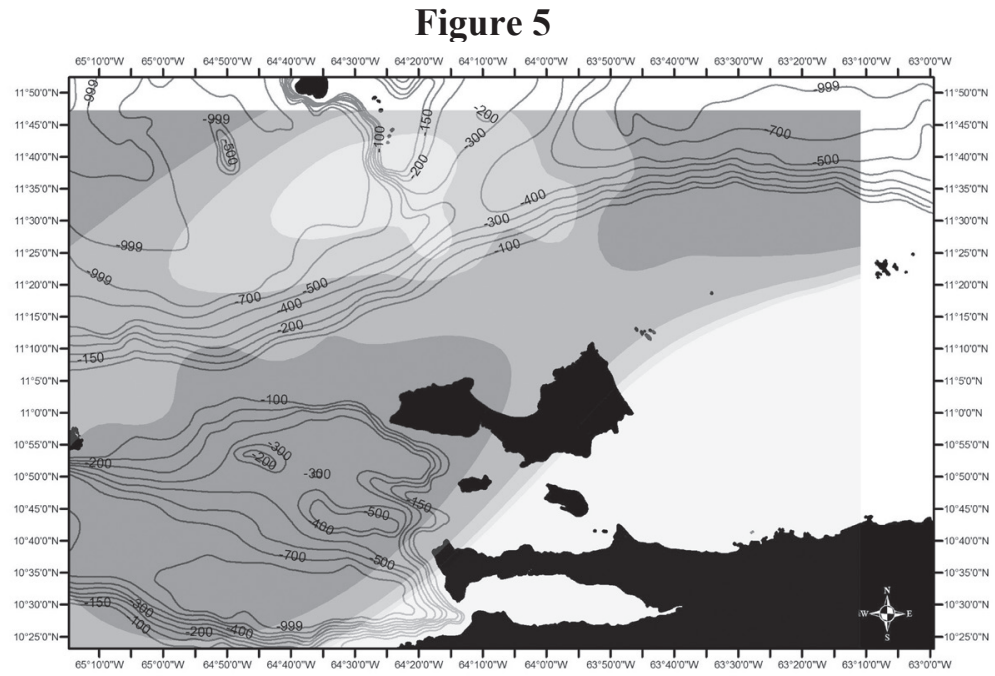

Prey biomass consumption by Atlantic spotted dolphin (S. frontalis), levels on consumption are represented by light gray to the lowest, and dark gray to the highest level of biomass removal. 


\section{Figure 6}

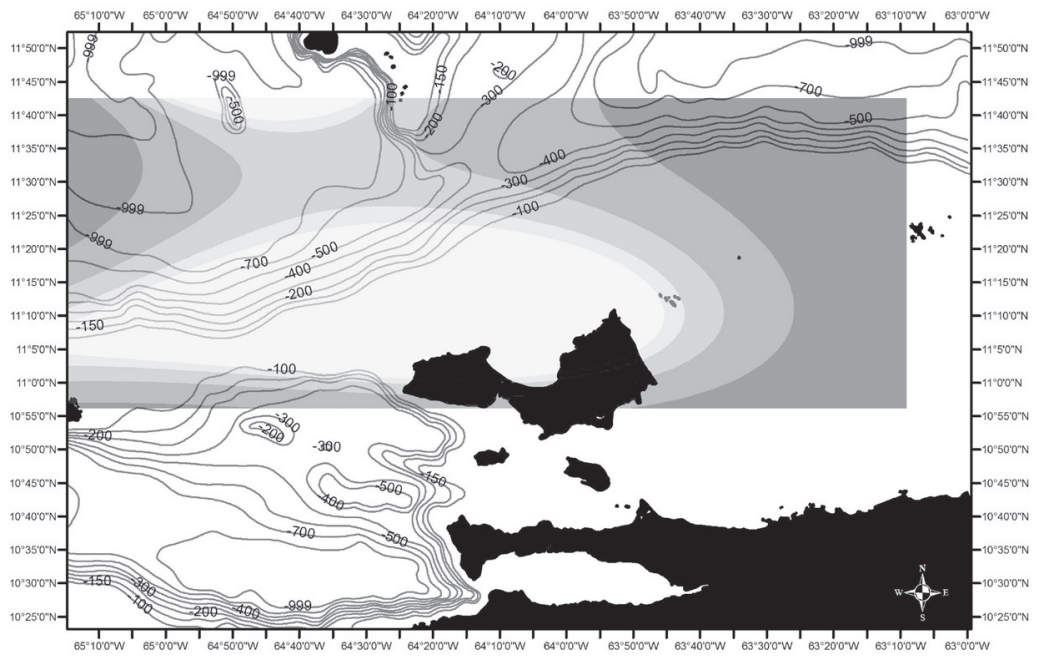

Prey biomass consumption by common bottlenose dolphin (T. truncatus), levels on consumption are represented by light gray to the lowest, and dark gray to the highest level of biomass removal.

are also considered as a key essential element for foraging niche definition. The distribution of biomass consumption by odontocetes, based on the relative abundance of toothed cetacean off the northeastern coast of Venezuela, primarily highlight clear evidence that predators are not uniformly distributed throughout the environment of the study area; and secondly, the location of the spatial arrangement of predatory patterns concentrate in discrete areas, giving insight into habitat use and resource partitioning.

The predatory pattern illustrated for Delphinus spp. and the prey biomass removal within shelf habitat represents the close spatial relation between predator- prey; particularly with the potential local prey of common dolphins, round sardinella, specifically on the locations referred by Freon et al. (1997) as key fishing grounds (areas 2 and 6; Figure 1). Consequently, locations of common dolphin prey biomass consumption would also coincide with the location of the most important coastal upwelling area off the coasts of the Central Paria and Araya Peninsulas. The occurrence of Delphinus spp. has been linked with areas of high productivity; as a result the species has been used as an indicator of upwelling waters in the Eastern Tropical Pacific (Ballance et al. 2006; Fernández et al. 2007; Fernandez \& Oviedo, 2009). Since predator biomass consumption distribution locally emulated that of its potential prey, 
and in this specific case, overlapped with areas of coastal up-welling, the spatial arrangement of the predatory patterns of common dolphins included discrete areas limited by boundaries, which defined a system diverging by physical and biological features.

The trends in distribution of estimated prey biomass removal by odontocetes particularly suggest the differentiation of foraging habitats, primarily in shelf waters, with a prey biomass that is comprised basically by demersal fish and small pelagics (including S. aurita). Additionally, cetaceans inhabiting transitional-oceanic depths were associated with a predatory pattern that probably relies on pelagic - mesopelagic squid and myctophids.

According to Pusineri et al. (2001), the patterns of trophic segregation within the cetacean community reported here, could be considered as an expression of differences in feeding tactics and habitats, similar to the trophic segregation of fin and minke whales off the Bay of Fundy, Canada (Ingram et al. 2007) and the habitat partitioning of dolphins in the mid-atlantic ridge (Doksæter et al. 2008). Provided that the spatial distribution of a given predators is conditioned by the specialized or generalized pattern of food consumption, and associated with the spatial arrangement of its prey (Doksæter et al. 2008, Forcada, 2002), the distribution of biomass consumption by top predators would be an indirect indication of prey location and abundance.

In general this approach combining elements of spatial and trophic ecology, has established clear patterns of habitat and resources partitioning, plus trends in occurrence dominancy in coastal and shelf areas of an important portion of the Venezuela's exclusive economic zone. However, the information presented here is conditioned by two important limitations: 1) the estimations of relative abundance are based on a large data set derived from a non-systematic research effort, and 2) the information on diets is not based on an local empirical evidence, it is based on the diet accounts proposed by Pauly et al. (1998), therefore it would not yield important local particularities.

Prey biomass consumption distribution assumes that predators' spatial arrangement match that of their prey. However, prey abundance by itself should not be considered as a unique proxy of habitat use, the abundance of cetacean predators also play a direct role, or an indirect pressure through "seascapes of fear" (sensu Wirsing et al. 2008), in the definition of both the spatial and foraging patterns of cetacean species.

According to Pauly and Zeller (2003), the spatial trend in regionalization, as the one presented in this report represents a key base-line to 
assess ecosystem health and evaluate management scenarios.

\section{ACKNOWLEDGEMENTS}

Cetacean data gathering was supported by funds from the Whale and Dolphin Conservation Society (WDCS), The Rufford Project Conservation Fund, and Cetacean Society International (CSI). Oceanographic data was provided by the Cariaco Project of the Estación de Investigaciones Marinas de Margarita (EDIMAR - FLASA) and the University of South Florida (USF), many thanks to Irene Astor and Ramón Varela, fisheries statistics were provided by INSOPESCA (Gobierno Bolivariano de Venezuela).

\section{BIBLIOGRAPHY}

Acevedo, R., Oviedo, L. \& Silva N. (2007). Identification of key areas for the conservation of misticete cetaceans in the waters near Margarita Island, Venezuela. Memoria Fundación Salle Cien. Nat., 167, 73-88. Ballance T. L., Pittman R. L., \& Fiedler P. C. (2006). Oceanographic influence of seabirds and cetaceans of the Eastern Tropical Pacific: a review. Prog. Oceanograp., 69, 360-390.

Barlow J., Kahru M. \& Mitchel B.G. (2008). Cetacean biomass, prey consumption and primary production requirements in the $\mathrm{Ca}$ lifornia Current ecosystem. Mar. Ecol. Prog. Ser., 371, 285-295.
Bearzi,G., Agazzi, S., Goncalvo, J., Costa, M., Bonizzoni , S., Politi, E., Piroddi, C., \& Reeves, R. (2008). Overfishing and the disappearance of short beak common dolphin from western Greece. Endangered Species Res., 5, 1-12.

Begon, M., Townsend, C. R. \& J. L. Harper. (2006) Ecology: from individuals to ecosystems. 4th ed. Blackwell Publishing, U.K.

Cañadas A.R., Sagarminga R. \& Garcia-Tiscar S. (2002). Cetacean distribution related with depth and slope in the Mediterranean waters off southern Spain. Deep Sea Res. Part I, 49 (11), 2053-2073.

Coll, M., Lotze, H.K., Romanuk, T.N. (2008). Structural Degradation in Mediterranean Sea Food Webs: Testing Ecological Hypotheses Using Stochastic and Mass-Balance Modelling. Ecosystems, 11, 939-960.

Costa, D.P. (2002). Energetics, pp. 387-394. In: Perrin W. F., Wursig B. and Thewissen J. G.. M. (eds.). Encyclopedia of Marine Mammals. San Diego: Academic Press. Davis R.W., Fargion G.S., May N., Leming T.D., Baumgartner M., Evans W.E., Hansen L.J. \& Mullin K. (1998). Physical habitat of cetaceans along the continental slope in the north-central and western Gulf of Mexico. Mar. Mam. Sci., 14, 490-507.

Doksæter, L., Olsen, E., Nøttestad, L. \& Fernö, A. (2008). Distribution and feeding ecology of dolphins along 
the Mid- Atlantic Ridge between Iceland and The Azores. Deep Sea Res. Part II, 55, 2053-2073.

Fernández, M. \& Oviedo L. (2009). Distribution and abundance of Delphinus delphis off the southern Pacific Coast of Costa Rica. Paper SC/SM3 presented to the IWC 60th Scientific Committee, June, Madeira, Portugal.

Fernández, M., Oviedo L., Echeverría, D. \& Goodman S. (2007). Cooccurrence of cetaceans indicator species in up-welling modified waters and tropical warm waters off Osa Peninsula, Costa Rica, Paper presented at the XVIII Biennial Conference on the Biology of Marine Mammals, Cape Town, South Africa. (unpublished). 4pp. [Available from the author].

Forcada, J. (2002). Distribution, pp 327-333. In: Perrin W. F., Wursig, B. and Thewissen, J. G. M. (eds.). Encyclopedia of Marine Mammals. San Diego: Academic Press.

Freón, P. El Khattabi, M., Mendoza, J. \& Guzmán, R. (1997). Unexpected reproductive strategy of Sardinella aurita off the coast of Venezuela. Mar. Biol., 128, 363-372.

Heithaus, M. R. \& Dill, L. M. (2002). Feedings Strategies and Tactics. Encyclopedia of Marine Mammals. In: Perrin W. F., Wursig B. and Thewissen J. G.. M. (eds.), San Diego; Academic Press.
Hui C.A. (1979). Undersea topography and distribution of dolphins of the genus Delphinus in the southern-California Bight. J. Mamma., 60, 521-527.

Hui C.A. (1985). Undersea topography and the comparative distribution of two pelagic cetaceans. Fish. Bull., 83, 472-475.

Ingram, S.N., Walshe, L., Johnston, D. \& Rogan, E. (2007). Habitat partitioning and the influence of benthic topography and oceanography on the distribution of fin and minke whales in the Bay of Fundy, Canada. J. Mar. Biol. Assoc., UK, 87, 149-156.

Naveira, J. L. (1996). El orden cetacea en la región nor-oriental de Venezuela. MSc. Thesis. Universidad de Oriente, Cumana, Venezuela.

Pauly D. \& Zeller D. (2003). The global fishery crisis as a rationale for improving the FAO's database of fisheries statistic. Part 1. Fisheries Center Research Report, Vol 11, 85 pp.

Pauly, D., Trites A. W., Capuli, E. \& Christensen, V. (1998). Diet composition and trophic levels of marine mammals. ICES J. Mar. Sci., 55, 467-81.

Perez, M. A. \& McAlister, W. B. (1993). Estimates of food consumption by marine mammals in the eastern Bering Sea. NOAA Technical Memorandum NMFSAFSC-14. US Deptartment of Commerce, Seattle, WA. 
Pianka, E.R. (1974). Niche overlap and diffuse competition. Proc. Natl. Acad. Sci. USA, 71, 2141-2145.

Pusineri, C., Chancollon, O., Ringelstein, J \& Ridoux, V. (2008). Feeding niche segregation among the northeast Atlantic community of top predators. Mar. Ecol. Prog. Ser., 361, 21-34.

Read, A. J. \& Brownstein C. R. (2003). Considering other consumers : fisheries, predators, and Atlantic herring in the Gulf of Maine. Conservation Ecology, 7, 2. [online, URL: http://www.consecol.org/vol7/iss1/art2]

Trites, A. W. \& Pauly D. (1998).Estimating mean body masses of marine mammals from maximum body lengths. Can. J. Zool., 76, 886-896.
Weir, C. R., Pollock, C., Cronin, C. \& Taylor, S. (2001). Cetaceans of the Atlantic Frontier, north and west of Scotland. Cont. Shelf Res., 21, 1047-1071.

Wirsing, A. J., Heithaus, M. R., Frid, A. \& Dill L. M. (2008). Seascapes of fear: evaluating sublethal predator effects experienced and generated by marine mammals. Mar. Mamma. Sci., 24, 1-15

Würsig, B. (2002). Ecology, Overview, pp 367-370. In: Perrin W.F., Wursig B. and Thewissen J. G.. M. (eds.). Encyclopedia of Marine Mammals. San Diego: Academic Press.

Zar, J.H. (1996). Biostatistical analysis. London: Prentice-Hall International (UK) Ltd. 